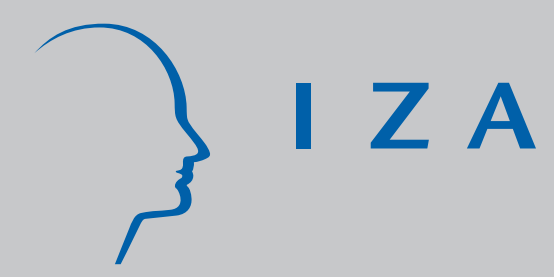

IZA DP No. 1073

The Changing Demand for Skills:

Evidence from the Transition

Simon Commander

J anos Kollo

March 2004 


\title{
The Changing Demand for Skills: Evidence from the Transition
}

\author{
Simon Commander \\ London Business School, \\ EBRD and IZA Bonn \\ Janos Kollo \\ Institute of Economics, Budapest \\ and IZA Bonn
}

Discussion Paper No. 1073

March 2004

\author{
IZA \\ P.O. Box 7240 \\ 53072 Bonn \\ Germany
}

Phone: +49-228-3894-0

Fax: +49-228-3894-180

Email: iza@iza.org

Any opinions expressed here are those of the author(s) and not those of the institute. Research disseminated by IZA may include views on policy, but the institute itself takes no institutional policy positions.

The Institute for the Study of Labor (IZA) in Bonn is a local and virtual international research center and a place of communication between science, politics and business. IZA is an independent nonprofit company supported by Deutsche Post World Net. The center is associated with the University of Bonn and offers a stimulating research environment through its research networks, research support, and visitors and doctoral programs. IZA engages in (i) original and internationally competitive research in all fields of labor economics, (ii) development of policy concepts, and (iii) dissemination of research results and concepts to the interested public.

IZA Discussion Papers often represent preliminary work and are circulated to encourage discussion. Citation of such a paper should account for its provisional character. A revised version may be available on the IZA website (www.iza.org) or directly from the author. 
IZA Discussion Paper No. 1073

March 2004

\section{ABSTRACT}

\section{The Changing Demand for Skills: Evidence from the Transition*}

Transition has involved major job destruction and creation. This paper examines the skill content of these changes using a detailed three country firm survey. It shows that transition has exerted a strong bias against unskilled labour who have lost employment disproportionately. Moreover, job creation in new firms tends to be biased against workers with low educational attainments and skills. The skill content of blue collar work has also shifted upwards. Although there is variation across the sampled countries, these appear to be common features. They will have major longer run implications for the level and structure of employment and for inequality through the distribution of earnings.

JEL Classification: J21, J23, J63, P31

Keywords: $\quad$ job reallocation, human capital, transition, Hungary, Romania, Russia

Corresponding author:

Simon Commander

London Business School

Sussex Place

Regents Park

London NW1 4SA

United Kingdom

Email: scommander@london.edu

\footnotetext{
* Thanks to Katrinn Tinn for excellent research assistance and to Mark Schankerman for suggesting some useful changes from an earlier draft, as well as to other seminar participants at LBS, EBRD and an IZA/WDI Workshop in Costa Rica in 2003.
} 


\section{Introduction}

It is widely believed that the planned economies entered transition rich in human capital relative to market economies at comparable income levels. This has been attributed to substantial public spending on education, in turn associated with high enrolment rates ${ }^{1}$. This positive inheritance was, however, qualified by the fact that while the share of educated workers in the labour force was relatively high, there was significant variation in the quality of education. Moreover, many of the skills imparted - in particular through vocational training - were highly process or firm specific. In some cases, this led to low adaptability of workers; a potentially major limitation once firms started to be restructured and when job mobility became a more important consideration. In addition, the wage distribution was severely compressed. This had obvious motivational consequences and was undoubtedly one of the factors ensuring that the productivity of workers was generally low.

Transition involved a rude shock to these arrangements. Jobs have been destroyed as firms have failed. Variation in the rate of job destruction across countries has been large. In the advanced reformers of Central Europe, substantial job destruction came quickly. The combination of resource reallocation and restructuring has also led to major job creation, but employment ratios have been stabilized at levels below the European average. By contrast, where reforms have proceeded more slowly - as in Russia and much of the CIS - reductions in working hours, wage arrears and a burgeoning informal sector have resulted. Further - and irrespective of the pace of reform - there is evidence of a severe fall in education spending and in the quality of educational services.

Although there is now a body of work that has looked at the employment flows from contracting to emerging sectors using enterprise level data ${ }^{2}$, job and worker reallocation has mostly been analysed with the assumption of homogeneous labour. There has been little hard evidence concerning the skill content of job losses and gains ${ }^{3}$. This paper begins to rectify this deficiency. The skills dimension of transition is critical in a number of regards. Given the inheritance, a reasonable prior might be that the transition countries, relatively rich in skills, would have generated jobs - contingent on the overall pace of reform - that were skill rich. The skill composition of the labour force should affect the types of jobs that firms wish to create - a thick market in skilled workers should lead to skilled jobs being posted as firms seek to match more efficiently human skills to physical capital. However, this prior has been

\footnotetext{
${ }^{1}$ For example, Flanagan (1997); Newell (2001)

2 See, Konings et al 1996, Bilsen and Konings 1998, Lehmann and Wadsworth 2000, Brown and Earle 2001
} 
to some extent undermined by recent studies of literacy and other basic skills. For example, in three out of the four transition countries involved in the OECD Literacy Survey, proficiency scores fell below the OECD average. One conjecture might be that the diffusion of human capital intensive technologies has been constrained by the low adaptability of workers and the deficiencies of adult training. ${ }^{4}$

Furthermore, transition has proceeded alongside a major shift in the relative demand for skill types in the market economies. Part of this appears attributable to the diffusion of ICT technology. There appears to be a robust link between ICT and investment in human capital and the skills of the labour force ${ }^{5}$. The balance of evidence from the OECD points to some substitution effects as lower skilled workers get displaced by machines, but the size of the net employment effect also depends on the degree to which ICT adoption raises the demand for skilled labour ${ }^{6}$. Certainly, given the initial conditions of relatively low levels of ICT adoption alongside relatively skilled workforces, we might have expected the transition countries to have accelerated adoption rates with implications for relative labour demand.

In this context, our paper takes a detailed look at the ways in which jobs have been destroyed and created and the relative skill content of such jobs across firms, sectors and countries. It is based on a survey of firms that was implemented in 2000 in three transition economies, Hungary, Romania and Russia. Country selection was guided by the wish to capture three distinct business environments. EBRD progress in transition indicators show that Hungary has proceeded further across all aspects of reform than Romania which, in turn, has proceeded further than Russia ${ }^{7}$. These countries can be seen to characterise different stages of transition, hence allowing some sense of the variation conditional on overall progress in reform. The survey allowed identification of skills by educational attainment as well as by discrete skill categories.

The paper identifies several key forces that have been at work. Even at the end of the 1990s transition has continued to reveal a strong bias against unskilled labour associated with the closure or restructuring of state and privatised firms. Unskilled labour has lost employment disproportionately. Further, job creation in new private manufacturing and service sector firms has been unambiguously biased against low skill workers. In addition, the

\footnotetext{
${ }^{3}$ An exception is Jurajda and Terrell 2001

${ }^{4}$ Case study evidence of low adaptability is provided in World Bank (1996) which analyses the Tungsram plant acquired by General Electric. For a more general, analytical consideration of the adaptability issue, see Aghion and Commander (2000).

${ }^{5}$ See, inter alia, Autor et al (1998); Chennells and Van Reenen (1999); Bresnahan et al (2001).

${ }^{6}$ See, for example, Falk (2001).
} 
skill content of blue collar work appears to have changed. However, the relative influence of these factors has varied substantially across the three countries covered in this paper. This variation in large measure reflects the different stages of reform that these countries have attained.

The paper is organised as follows. Section 2 introduces the dataset. Section 3 looks at net changes to jobs, and relates them to changes in relative wages. Section 4 looks at what the future is likely to hold, given the presence or absence of perceived labour hoarding and shortages of particular skills. Section 5 provides estimates of the wage elasticities of demand and Section 6 concludes.

\section{Data description}

The analysis in the paper is based on a dataset collected by the EBRD designed to allow a more quantitative and detailed look at the changing structure of skills and work. A survey of 921 firms in the three countries - Hungary, Romania and Russia - was implemented in mid-2000. For each country, the sample was stratified both by employment size and sector. Farms and rural firms were excluded from the sample. Sampling occurred over a wide regional base. In Russia, firms were interviewed in 25 oblasts or regions; in Romania in 8 regions and in Hungary in 6 districts. For the majority of the quantitative questions, the reference period covered 1997 to 2000 thereby yielding a maximum of four data points. While, the dataset is relatively small, it has properties that are generally absent in the larger datasets commonly used to analyse labour market behaviour. These include information on ownership, the age of the firm and capital stock, as well as very detailed breakdowns of the skill features of the labour force over time. Some simple descriptive statistics are provided in Table 1 which show that in all three countries the bulk of interviewed firms were in manufacturing and had over 50 employees. Large firms with over 250 employees accounted for over a third of the sample and were more populous in Romania and Russia than in Hungary. While most firms were established pre-1990, a significant minority of firms in Romania and Hungary were established after the start of transition.

Skills were measured in two ways in the survey. First, firms were asked to classify their jobs on the basis of skill content using four occupational grades: (i) unskilled and semiskilled blue collar, (ii) skilled blue collar, (iii) white collar and, (iv) managerial. Second, they were asked to provide the composition of each occupational group on the basis of workers'

\footnotetext{
${ }^{7}$ For the latest measures, see EBRD (2003).
} 
educational backgrounds again using four categories. These were, (a) primary school, (b) vocational training school (providing no certificate required for entry to higher education), (c) secondary school and (d) college or university ${ }^{8}$. While it is common to assume that education is a decent proxy for skills, it is clear from this dataset that changes of the educational mix within skill grades constitute a key component of restructuring.

There is also an important qualification to be made. There have been - and are - salient differences in the educational and job classification systems operating in the three countries. For example, primary school has ten grades in Russia but only eight grades in Hungary and Romania since 1990. Vocational education in Hungary has generally been for three years and been without certification. In Romania it was partly provided in the primary schools. By contrast, in Russia, there have been two types of vocational training, one for lower level skills of two years; the other of four years for junior professionals. Both have been certified. Given these differences we analyse the data at a country level and pay close attention to the local context when drawing conclusions. Finally, Russian firms reported wages only by skill grades. As a result, skill-specific changes in Russia are analysed separately.

In the paper we also classify firms by whether they have destroyed or created jobs or by net changes within broad sectors distinguished by type of activity (manufacturing versus tertiary) ${ }^{9}$. With respect to the latter, we distinguish between an 'old sector' comprising stateowned or privatised domestic firms, which were established under socialism and have equipment inherited from that period ${ }^{10}$. The 'new sector' consists of firms established after 1990 or owning new equipment (i.e post-1990 vintage) or majority foreign-owned enterprises irrespective of their date of establishment and age of their equipment ${ }^{11}$. Table 1 shows that there is some variation across countries. In Hungary the share of new firms in manufacturing is above 60 percent as against under 29 percent in Russia. However, most tertiary sector firms in Russia are new and overall the share of new firms in total sampled firms ranges between 51-64 percent. Disaggregating in terms of ownership, nearly three quarters of the state firms were 'old' as against 57 percent of firms that were privatised by 2000 .

\footnotetext{
${ }^{8}$ At times, these are abbreviated to BCU, BCS, WC and MAN for the skills categories and to PRIM, VOC, SEC and HIGH for the educational levels.

${ }^{9}$ An obvious question arises concerning the impact of break-ups, mergers, and title changes that may inflate rates of job destruction and creation. In our survey, over 90 percent of the firms in the sample were operating continuously between 1997 and 2000 .

${ }^{10}$ Firms were asked to tell the average age of the equipment they use to produce their leading product or provide their most important services. Equipment was classified as 'old' in case average age exceeded 10 years.

${ }^{11}$ For old-sector firms $a$ and $b$ and $c$ applies. For new-sector firms $d$ or $e$ or $e$ holds.
} 


\subsection{Job creation and job destruction: some aggregates}

Prior to discussing our findings, we need to signal a possible source of measurement error. When using standard firm registers, the break-ups, mergers and title changes accompanying transition tend to inflate rates of job destruction and creation. This risk exists, although to a much lesser extent, in our survey. Over 90 percent of firms in the sample were operating continuously between 1997-2000. However, among the firms classified as 'de novo' there were six large utilities reporting 1998 as their date of establishment and no employment in 1997. This is obviously not credible and to avoid measurement error we used the reference period 1998-2000 for Romania throughout this paper ${ }^{12}$.

Before turning to analysis of skill-specific changes, a brief overview of job reallocation rates based on changes in the aggregate employment of firms is presented in Table 2 and compared with earlier estimates for the three countries ${ }^{13}$. What emerges is that not only are there significant differences in annual creation and destruction rates between 1998-2000 but also with respect to earlier observations. Thus, job creation rates in all countries are higher at the end of the 1990s than earlier in the transition, while job destruction rates have moved in different directions. In Romania our survey picks up far higher destruction rates relative to 1993/94, while in Hungary and Russia destruction rates have declined. This reflects different stages of transition in the case of Romania and Hungary while in the Russian case the sharp fall in destruction in 1999/2000 reflects the strong growth in output following the 1998 devaluation as well as the generally slow pace of reallocation. These differences are reflected in the net changes, with Romania experiencing a particularly sharp decline in total employment.

Table 2 also indicates that - as might be expected - that there are large differences in creation, destruction and net rates for different ownership types. Job creation rates in Hungary and Romania were significantly higher in new private firms, while in Russia this was the case for both new private and privatised with new equipment. Job destruction rates were largest in all countries for state owned and privatised firms with old equipment. In all countries there were negative net rates for state firms but there was large, cross-country variation. In Hungary

\footnotetext{
${ }^{12}$ In an earlier version of this paper, the firms in question were classified as de novo. This did not significantly affect the results. Commander and Kollo (2001). An alternative approach would be to exclude them from the sample.

${ }^{13}$ The rates are defined as the sum of net changes in expanding (contracting) firms over the mean stock of jobs in all firms. The jobs created in (genuine) new firms are included.
} 
and Romania only new private firms experienced positive net job growth, while in Russia this was also true for privatised firms with new equipment ${ }^{14}$.

\subsection{Changes by skills and education}

How have different skill categories been affected? Table 3 shows the net relative change of employment between 1997-2000 in the three countries. What emerges is that while aggregate employment changed very little in Hungary and Russia and fell by over 1/10 in Romania, there was a clear pattern in the distribution of skill changes. In particular, there is an unambiguous decline in unskilled employment across all countries with most of that concentrated among workers with low educational attainments. This was particularly marked in Romania where there was a decline of between $16-20 \%$ for workers with primary or vocational education. By contrast, Table 3 also shows that there has been a growth in employment for more educated workers. There is also evidence of a shift towards more educated labour within each occupational grade, including among unskilled blue collar jobs. Although these within-group shifts have been significant, the combined effect on the occupational composition has been trivial. In terms of the skill categories, it is notable that job destruction has fallen mostly on blue collar workers - mainly the unskilled, although the balance between skilled and unskilled has varied across country. For Russia, while we find that there was a significant decline in unskilled blue collar employment and a lesser decline for white collar jobs, employment of both skilled blue collar workers and managers rose.

Disaggregating in terms of broad sectors as well as 'old' and 'new' sectors, Table 4 indicates that in Hungary, 'old manufacturing' destroyed all types of jobs except those of relatively highly educated manual workers and white collar workers. Most of the net loss was concentrated among workers with low educational attainments. The tertiary sector's contribution to employment change was generally modest but almost always positive. 'New manufacturing' added 12-13 per cent to the stock of blue collar jobs held by relatively highly educated workers, but reduced the employment of low educated blue collars by around 2-3 per cent. In Romania across-the-board job destruction by 'old' manufacturing firms has occurred with a further bias against low-educated workers within each occupational group. 'New manufacturing' tended to destroy jobs for low-educated workers and was generally unable to replace the jobs lost in state-owned or 'old' privatised industrial enterprises. The

\footnotetext{
${ }^{14}$ We lack information on firms that closed, so the the destruction rates presented in the paper will be underestimates
} 
tertiary sector was more successful in mitigating the impact of industrial decline on low-skill blue collar employment but the net outcome was nonetheless negative everywhere in the lower segments of the labour market. Russia looks a bit different. There is no strong difference between old and new sectors in either manufacturing or the tertiary sector. In both parts of manufacturing there is some weak evidence of job destruction being concentrated on low skill-education jobs and no clear pattern for the tertiary sector.

We now try to explain the variation in the net rates of change in employment observed in the firm-skill-education cells. We regress the net measure on dummies for skill, sector, size and branch, weighting the observations by employment and clustering for firms. In other words, we adjust the standard errors under the assumption that the net rates are independent between, but not within, firms. Despite their simplified nature, these estimations summarised in Table 5 - provide a crisp summary of the changes. In the case of Hungary and Romania old manufacturing firms principally cut unskilled-low education jobs, while creating jobs for relatively well educated workers, including among unskilled blue collar positions. Relative to old manufacturing, employment in new manufacturing grew significantly but there was relatively little difference between manufacturing and tertiary sectors. In Romania the gap between the sectors was larger. By contrast, in Russia, the results reinforce the finding that employment change was only loosely correlated with skills and neither the manufacturing-services divide nor the 'new' / 'old' distinction have affected its variation. Small firms have, however, grown faster and there is some evidence that their labour demand was significantly biased toward highly educated white collars as well as skilled blue collar workers with vocational training.

In short, these estimations emphasise the fact that changes of employment have differed between interactions of skill grades and education, while also emphasising the importance of the 'new' / 'old' distinction in the more reformed countries. As might be expected job growth throughout has been concentrated in both the 'new' sector and in services. However, there has been significant variation across country both in terms of the magnitudes of the changes as also their distributions. This suggests that the demand for skills is shaped by factors that have come together somewhat differently across the three countries under examination.

This brings us to the issue of the role of within and intra-firm effects. Table 6 provides three measures; (1) overall: the sum of net changes/ stock, (2) firm-specific: the sum of firmspecific net changes / stock and, (3) intra-firm: the sum of skill-specific, intra-firm changes / 
stock. These are calculated as follows. The firm-specific change of employment (n) of a given educational group is defined as $-\Delta n^{F}=n^{0}\left(N^{1} / N^{0}\right)-n^{0}$, where $N$ stands for total employment in the firm. This is the change that would have occurred in case of skill-neutral expansion or contraction. Intra-firm, skill-specific change is defined as $\Delta \mathrm{n}^{\mathrm{I}}=\Delta \mathrm{n}-\Delta \mathrm{n}^{\mathrm{F}}$. Firm-specific changes were removed from the data. The overall or net measure is the sum of net changes/stock.

What Table 6 demonstrates very clearly is that workers with low education are at far higher risk of job loss not only because their firms are likely to contract but because intra-firm demand has also been biased against them. For both Romania and Russia all groups would have lost in the case of skill-neutral changes of employment but skill-specific changes maintained a strong relative demand for highly educated workers. However, in Hungary growing demand for highly educated workers was fully explained by the skill-neutral expansion of firms employing high skilled workers.

Finally, it is worth emphasising the fact that although job creation appears to be biased toward workers with more education, it is also the case that educated workers have continued to lose their jobs in manufacturing; testimony to the protracted length of the shake-out occurring amongst firms inherited from the previous system.

\section{Explaining changes in relative wages and employment}

That there have been changes in relative wages and employment is clear. The challenge is understand whether they have been driven by supply or demand side factors. Although this is hard to answer with such limited observations on time, we start by simply relating changes in relative wages to employment and then implement the procedure employed by Katz and Murphy (1992) to try and disentangle supply and demand side shifts.

Relating the change in relative wage to the change in employment ${ }^{15}$, we find that in the Hungarian case the two indicators moved together. The relative wages of blue collars with primary education fell parallel with their declining share in employment. By contrast, all groups with secondary or higher education (apart from managers with a secondary school background) improved their relative position in terms of both employment and wages. The groups where rising employment levels were associated with falling relative wages, and vice

\footnotetext{
15 The ratio of a skill group's share in job creation to its share in job destruction (to remove the effect of aggregate employment) is used as the measure of relative employment change. The relative wage of skill group $\mathrm{i}, \mathrm{j}$ at time $\mathrm{t}$ is defined as: $\mathrm{r}_{\mathrm{ijt}}=\left(\mathrm{w}_{\mathrm{t}}{ }^{\text {ref }} / \mathrm{W}_{\mathrm{t}}\right) \exp \left(\mathrm{b}_{\mathrm{ijt}}\right)$, where the $\mathrm{b}$-s are estimated with cross-section wage regressions. Controls for region, sector and firm size were included to capture compensating differentials.
} 
versa, all had vocational schooling. For Romania, the picture is less clear. However, only in the case of four groups - comprising 29 per cent of the population - did wages and employment move in the opposite direction. Blue collar workers mostly lost, while whitecollar, highly educated labour gained in terms of relative employment and wages ${ }^{16}$.

Katz and Murphy (1992) provide a useful way of trying to explain changes in relative wages. Their framework has $\mathrm{K}$ types of labour inputs. Factor demands can be expressed as; $X_{t}=D\left(W_{t}, Z_{t}\right)$, where $X_{t}=K \times 1$ vector of labour inputs employed in the market at time t, $W_{t}=K \times 1$ market prices for these inputs at time t. $Z_{t}=m \times 1$ vector of demand shift variables at time t. This can be written in terms of differentials as: $d X_{t}=D_{w} d W_{t}+D_{z} d Z_{t}$ Assuming a concave aggregate production function, the $K \times K$ matrix of cross price effects on factor demands, $D_{w}$ will be negative semidefinite, implying $d W_{t}^{\prime}\left(d X_{t}-D_{z} d Z_{t}\right)=d W_{t}^{\prime} D_{w} d W_{t} \leq 0$ In other words, changes in factor supplies - net of demand shifts - and changes in wages will negatively covary.

We start by looking at whether the data are consistent with stable factor demand, with changes in relative wages being driven by factors, such as educational attainment rates. In this case, wages will generated by relative supply changes with factor demand stable.

$$
d W_{t}^{\prime} d X_{t} \leq 0
$$

To do this, we use information from the survey. For K, we have 16 groups: 4 occupation groups (managerial, white collar, skilled blue collar, unskilled blue collar) * 4 education groups (higher, vocational, secondary and primary). Relative wages were calculated as follows; $w_{k t}=($ estimated wage of group $k$ at year $t) /($ wage index at $t)$ relative wage of group $\mathrm{i}$ at $\mathrm{t}$ : wage index at $t=\left[\begin{array}{l}\text { av wage of group } 1 \\ \vdots \\ \text { av wage of group } K\end{array}\right]\left[\begin{array}{l}\frac{a v \cdot \text { full-time employment of group } 1 \text { over time }}{a v \cdot \text { full-time employment over time }} \\ \vdots \\ \frac{a v . \text { full-time employment of group } k \text { over time }}{a v \cdot \text { full-time employment over time }}\end{array}\right]$ The wage index at time $\mathrm{t}$ being the simple average of estimated wages of groups $1 . . \mathrm{K}$ in year t.

\footnotetext{
${ }^{16}$ Results available on request
} 
The supply of group i at time t;

$x_{i t}=($ employment of group $i$ at $t)($ av. relative wage of group $i$ over time $)$

This then allows testing for fixed factor demand for a number of time periods;

$\left[\ln w_{t}-\ln w_{\tau}\right]^{\prime}\left[\ln x_{t}-\ln x_{\tau}\right]$ Table 7 gives the inner products are reported for both countries.

As can be seen, the bulk of the numbers are positive - in the case of Hungary all are positive This suggests that supply shifts cannot be the sole explanatory factor.

We now turn to look at the possible role of demand shifts between and within sectors. For this exercise, we have data on; 4 education groups: higher, vocational, secondary, primary; 4 occupation groups: managerial, white collar, skilled blue collar, unskilled blue collar and, 12 industry groups: (new/old)*(manufacturing/tertiary)*(small/medium/large size)

Relative wages that are used to weight employment are calculated as above.

The demand shift measure is: $\Delta X_{k}^{d}=\frac{D_{k}}{x_{k}} \sum_{j} \frac{x_{j k} \Delta x_{j}}{x_{k} x_{j}}$ where the base period is the average of 1998-2000

The overall (industry-occupation) demand shift index is $\Delta X_{k}^{d}$, where $\mathrm{j}$ indexes all industryoccupation cells. This can be decomposed into; a between industry demand shift index $\Delta X_{k}^{b}$, where $\mathrm{j}$ indexes industry groups and a within industry demand shift index $\Delta X_{k}^{w}=\Delta X_{k}^{d}-\Delta X_{k}^{b}$. Indices are reported in form of $\ln \left(1+\Delta X_{k}\right)$

Table 8 reports the result of these exercises where between and within decomposition are done for each pair of years, as well as for the longer period from 1997-2000. In the Hungarian case, what emerges is there is little evidence of strong differential between effects. For the within decompositions, the low education categories tend to be negatively signed while high education appears to experience a positive shift. Looking at the longer period 1997-2000 - the overall effect for both higher and vocational education is positive, particularly in the former instance.

In the Romanian example, the sign on the annual between columns are mostly negatively signed. The within columns indicate a positive - but small - number for those with higher education. The overall effect is negative for all skill categories. However, in the case of the longer reference period, the overall effect for higher educated workers is strongly positive, driven mostly by within effects. 
These results suggest that shifts in the skill composition were mostly demand driven in Hungary but more ambiguous in Romania. However, for the latter there is some evidence over the three year period that there was as strong positive shift in favour of workers with higher education.

Finally, turning to Russia, the data show a 21 per cent decrease in employment of unskilled blue collars, and 6 per cent fall in white collar jobs, while the number of skilled blue collars and managers increased by 7 and 3 per cent, respectively. A shift from unskilled to skilled manual workers could be observed in 'new-type' firms, while the old sector shed mostly white collars. Regressions similar to those presented for Hungary and Romania could not identify significant differences between sectors or branches, and pointed to higher than average rates of growth in groups with vocational and higher education (where these variables were available). The data on wage changes - see Table 9 - suggest no significant difference between workers of creating and destroying firms, in the case of skilled labour. However, the relative wages of unskilled blue collars fell substantially, by 12 percentage points, and the decline was driven by wage cuts in contracting and stagnating enterprises.

\section{Can demography explain the changes?}

In principle, a major shift towards more educated labour could have happened without any shift in the demand for skills through demographic change. Retiring workers would have been replaced by better educated school leavers. In this case, increased levels of skills would have been largely associated with replacements on an intra-firm, intra-occupational basis. Using the survey evidence, we are able to give an upper-bound estimate for such substitution between low and high-educated workers, by disentangling cases when job creation for the latter group was associated with destruction of low-skilled employment ${ }^{17}$. Denoting firms with i, skill grades with $\mathrm{j}$, the high and low-educated groups with $\mathrm{H}$ and $\mathrm{L}$, and the number of jobs created or destroyed with $\mathrm{dL}$, substitution can be defined as:

$$
\mathrm{s}_{\mathrm{ij}}=\mid \begin{array}{lll}
0 & \text { if } \mathrm{dL}_{\mathrm{ij}}^{\mathrm{H}}<0 & \left(\text { no creation }=>\mathrm{s}_{\mathrm{ij}}=0\right) \\
\mathrm{dL}^{\mathrm{H}}{ }_{\mathrm{ij}} & \text { if } 0<\mathrm{dL}^{\mathrm{H}}{ }_{\mathrm{ij}}<\left|\mathrm{dL}_{\mathrm{ij}} \mathrm{L}_{\mathrm{ij}}\right| & \text { (less creation than destruction }=>\mathrm{s}_{\mathrm{ij}}=\text { creation) } \\
-\mathrm{dL}^{\mathrm{L}}{ }_{\mathrm{ij}} \text { if } \mathrm{dL}^{\mathrm{H}}{ }_{\mathrm{ij}}>\left|\mathrm{dL}_{\mathrm{ij}}^{\mathrm{L}}\right| & \text { (more creation than destruction }=>\mathrm{s}_{\mathrm{ij}}=- \text { destruction) }
\end{array}
$$

\footnotetext{
${ }^{17}$ The estimate is upper-bound because the jobs created and destroyed may have been located in different departments.
} 
$\mathrm{S}_{\mathrm{j}}=\operatorname{Sum}_{\mathrm{i}}\left(\mathrm{S}_{\mathrm{ij}}\right) / \operatorname{Sum}_{\mathrm{i}}\left(\mathrm{dL}_{\mathrm{ij}}^{\mathrm{H}}\right)$ s.t. $\mathrm{dL}^{\mathrm{H}}{ }_{\mathrm{ij}}>0$ giving an upper-bound estimate of intra-firm, intraoccupation substitution as a proportion of job creation. Analogous to $S_{j}$ we can define a replacement ratio $\left(\mathrm{R}_{\mathrm{j}}\right)$ to look at how many jobs lost by low-educated workers were filled by applicants with more education within the same enterprise $\left(r_{i j}\right)$. Summing $r_{i j}$ by firms gives an estimate of within-firm replacement as a proportion of total jobs lost.

Estimates of $S_{j}$ and $R_{j}$ are presented in Table 10. 'Low education' comprises primary school in the case of unskilled blue collars; the primary or vocational level in the case of skilled blue collars; and primary, vocational, or secondary background in the case of white collars. The data suggest that only 2-16 per cent of total destruction was replaced by jobs created for more educated workers within the same enterprise (with the exception of skilled blue collars in Russia). ${ }^{18}$ Taking job creation for relatively high-educated employees onehundred, the share of substitution appears to be somewhat higher, falling to a range between 15 and 35 per cent. We can clearly observe a bias against the low-educated in destruction, and preference for the better educated in creation. Recalling that the estimates of $S_{j}$ and $R_{j}$ are biased upwards, these magnitudes may point to a weak role for demographic change.

\section{Looking forward: evidence on labour hoarding \& shortages}

The previous sections have drawn attention to the significant changes in the skill composition that have occurred. However, these changes might only reflect temporary adjustments. Given that we can only look at persistence in either job creation or destruction rates, this may not be an adequately long period to establish whether such adjustments have been temporary ${ }^{19}$. Persistence in job destruction has been very high, typically in excess of 90 per cent. Persistence in job creation has also been high, but with greater variation across skill categories. This suggests that much of the adjustment has not been temporary in nature. Further, such adjustments obviously depend on how far firms believe their employment levels are relative to desired or 'equilibrium' levels. Firms in the survey were asked how their actual level of employment compared with the desired level given their existing capital stock, technology and output. The answers were given for the four skill groups using a categorical scale and the findings are summarised in Table $11^{20}$. The share of firms reporting higher than

\footnotetext{
${ }^{18}$ In the Russian case the calculations exclude the unskilled category for lack of data on their educational composition.

${ }^{19}$ The persistence rate for job creation is measured by how many jobs created between year $t$ and $t+1$ survive until year $t+2$ with the destruction rate defined analogously. Results available on request.

${ }^{20}$ Redundancies could be in the following ranges; between $5-10 \%, 11-20 \%$ and over $20 \%$; shortages between 5 $10 \%$ and over $10 \%$.
} 
desired levels ranged between 3-9 per cent in Hungary, 7-13 per cent in Romania, and 5-10 per cent in Russia. Using the mean of a given skill category and replacing 'over 20 per cent' with 25 per cent as a lower bound and 40 per cent as the upper bound, we can roughly estimate the magnitude of excess employment in terms of workers. The lower and upper estimates fall fairly close to each other with even the latter indicating negligible ratios of between 0.3 to 3.7 per cent. In Hungary, the excess workforce was evenly distributed across sectors. In Romania, 76 per cent was concentrated in those old-sector firms which were downsizing between 1998 and 2000 - suggesting that despite the huge employment losses of 'old' firms their process of adjustment had not yet been completed. By contrast, in Russia 68 per cent was employed in old-sector firms which had not downsizing before 2000 - indicating the very limited impact of reforms. Altogether, 98 per cent of the redundant Russian workforce was employed in the old sector, as opposed to 82 per cent in Romania, and only 36 per cent in Hungary. The proportion of firms reporting lower than desired levels was somewhat higher, particularly in the case of skilled blue collars (17 per cent in Romania 36 per cent in Hungary and Russia). The estimate of the number of workers is however low: 4-5 per cent in the case of skilled blue collars and below 2.5 per cent in other categories ${ }^{21}$.

From these data, a picture of further downward adjustments to employment emerges for Romania despite very high rates of job destruction in the old sector during 1998-2000. Similarly, in Russia a relatively large proportion of firms in 'old' manufacturing reported excess unskilled workers. The locus of job destruction will likely remain in the old sector in these countries. While the cross-country differentials are telling, the lesson from these figures is that firms' actual employment levels are infrequently, and only marginally, higher than their desired level in Central Europe. The fact that Russian firms - despite relatively low net adjustments to employment - reported low labour hoarding appears perverse. It likely reflects the general absence of restructuring - even indeed a lack of understanding of what restructuring may entail in terms of relative job losses - and the curious mix of adjustment measures taken by many 'old' firms; namely wage and hours adjustment.

\footnotetext{
${ }^{21}$ Of course, firms reporting 'shortages' may not be able to finance a 'desired level' of employment. By contrast, higher than desired levels imply an actual cost. This suggests that the information on excess employment is likely to be more robust than that on shortages.
} 


\section{Wage elasticities - Cross section estimates}

If firms are indeed at or close to their optimum, we can estimate their demand for skills using a simple static model derived from the translog cost function. Denoting output with $\mathrm{Y}$, factor quantities and factor prices with $\mathrm{X}_{\mathrm{i}}$ and $\mathrm{p}_{\mathrm{i}}$, the minimum cost $\left(\mathrm{C}^{*}\right)$ function is:

(2) $\ln C^{*}=v_{0}+v_{y} \ln Y+\sum_{i} v_{i} \ln p_{i}+\frac{1}{2} \sum_{i} \sum_{j} \gamma_{i j} \ln p_{i} \ln p_{j}+\sum \gamma_{i y} \ln p_{i} \ln Y+$ remainder

Applying Shephard's lemma, and neglecting the remainder we can derive a system of optimal cost share equations ${ }^{22}$ :

(3) $\partial \ln C^{*} / \partial \ln p_{i}=p_{i} X_{i} / \sum_{i} p_{i} X_{i}=s_{i}=v_{i}+\sum_{i} \gamma_{i} \ln p_{i}+\gamma_{i y} \ln Y$

s.t.. $\gamma_{i j}=\gamma_{j i} \quad \forall i \neq j$ and $\quad \sum_{i} \gamma_{i}=\sum_{j} \gamma_{j}=\sum_{i} \gamma_{i Y}=0$

The own-price elasticities $\left(\varepsilon_{\mathrm{ii}}\right)$ and the cross-price elasticities $\left(\sigma_{\mathrm{ij}}\right)$ can be computed using the estimated parameters and observed cost shares:

$\varepsilon_{i i}=\left(\gamma_{i i}+s_{i}^{2}-s_{i}\right) / s_{i}$

$\sigma_{i j}=\left(\gamma_{i j}+s_{i} s_{j}\right) / s_{i}$

We lack data on capital costs, so that we have to estimate (3) by distinguishing three types of labour - unskilled blue collar, skilled blue collar, and white collars including managers restricting the analysis to firms reporting their net sales revenues. ${ }^{23}$ Further loss of observations comes from the exclusion of firms employing only one or two types of labour. This means that we can estimate the equations for 180 Hungarian, 242 Romanian, and 148 Russian firms respectively. ${ }^{24}$ The estimations were repeated for 133, 144 and 98 manufacturing firms, respectively. Table 12 shows that the own-wage elasticities are correctly signed (with the exception of Russian white collars), and decrease as we move from unskilled labourers to more skilled groups. The estimates for white collars and skilled blue collars are

\footnotetext{
${ }^{22}$ For the derivation, see Hamermesh (1993).

${ }^{23}$ We also lack information on social security contributions but these, being linear in wages, do not affect the cost shares once capital cost is excluded.

${ }^{24}$ Though the dependent variables are the same in all equations, an OLS estimator would still be inefficient because of the restrictions. Therefore Zellner's Seemingly Unrelated Regressions procedure was used.
} 
lowest in Russia, slightlz higher in Romania, and much higher in Hungary ${ }^{25}$. The demand for unskilled blue collars seems to be highly responsive to wages in all countries. With one exception, unskilled blue collar workers and other groups appear to be either price-substitutes or nearly independent.

Finally, we can put these estimates together with those for reported disequilibria. The expectation is that positive residuals from the skill share equations (indicating higher than desired or optimal levels of employment) would be positively correlated with reported excess employment. Conversely, negative residuals would be expected to raise the probability of complaints of 'shortages'. Univariate logits - with a dummy for reported excess labour on the left hand and the estimation residual on the right hand - found that the linkages between reported and estimated excess employment were indeed positive, although not always significant. When reported shortages were regressed on the residual we got negative and/or insignificant coefficients in all cases bar one ${ }^{26}$.

\section{Conclusions}

This paper has broken new ground in looking at changes to the skill distribution in three transition countries. What emerges is informative. There has been large scale job destruction in 'old' manufacturing firms that had survived the first seven years of transition without either modernising their equipment and/or finding foreign investors. These enterprises destroyed jobs on a massive scale in Romania and, somewhat less dramatically, in Hungary. In Russia, the rate of job destruction has been notably lower: a function of the far slower pace of reform and pressure to restructure. In Central and Eastern Europe, the difference between 'old' and 'new' manufacturing in terms of their respective demand for skills has been in degree rather than type. Changes in the skill profile of 'new' manufacturing were achieved through a mix of job creation and destruction while in 'old' manufacturing selection in downsizing appears as key. Total employment in 'new' manufacturing grew at a modest rate of just under 4 percent in both Hungary and Romania. The highest rates of growth were with jobs for highly educated white collars, as well as for blue collars with 'above standard' levels of education. At the same time, 'new' manufacturing created hardly any for either unskilled or skilled blue collar workers as well as white collar workers with limited

\footnotetext{
${ }^{25}$ Kertesi and Köllõ (2002) - using another data base which included capital costs - estimated an own-price elasticity of -1.8 for workers with primary and vocational education, and -1.0 and -0.6 for two groups of skilled labour in 1999. These values are consistent with our findings.

${ }^{26}$ These results are available request
} 
education. While changes in the skill composition have been in similar direction, the magnitudes have been rather different. In Hungary the growth of a dynamic 'new' manufacturing sector resulted in replacing around 85 percent of the jobs lost in the 'old' sector. This ratio was much lower in Romania at only 57 percent.

The services sector has had a rather different impact on the demand for skills. In Romania, a country where the services sector was particularly restricted under planning, its subsequent growth has largely involved creating jobs for blue collar workers. In Hungary, where the 'gap-filling' growth of services was exhausted by the mid 1990s, relative demand grew substantially for only two categories: blue collar workers with secondary education and highly educated white collars.

For Russia, the overall picture is quite comparable to the other two countries in one respect. Unskilled blue collar employment has been destroyed at a high rate while employment of other skill categories has evolved more favourably. The main conclusion from our data concerns oversized, 'old' manufacturing firms cutting ancillary low-skilled jobs and unproductive white-collar positions. The differences between firms undertaking successful 'strategic restructuring' and others have not been as clearly transmitted to the labour market as in Hungary or Romania, not least because of the recourse to wage arrears, reductions in working hours, temporary leaves and other partial adjustment measures.

Turning to the demand for skills, the shift towards highly educated white collar workers is a marked feature in all three countries. An equally unambiguous shift can be observed from less to more educated blue collar workers or, from unskilled to skilled manual workers in Russia. Indeed, the highest growth rates can be observed for unskilled blue collar workers with higher than primary education and skilled blue collar workers with secondary education. The presence of education-specific wage differentials within blue collar skill grades - combined with the fast-growing employment of educated manual workers and firm's complaints of skilled blue collar 'shortages' - lead us to conclude that the skill content of blue collar work has been changing substantially. This transformation seems to be at least as important as the increased bias toward employment of more highly educated workers.

The change in the demand for skills emerging from the analysis of our survey has some important implications. Workers with limited education have lost their jobs disproportionately and their relative wages have also been falling. Although the elimination of the labour hoarding of low skilled workers appears to have been nearly completed in Hungary and Romania, but less so in Russia, new firms and sectors have also, in the net, destroyed 
rather than created low-skill jobs. We have also observed clear shifts from the employment of relatively low to high-educated labour within the blue collar category. Our results also show that the demand for low-skilled labour has been highly responsive to wages. However, if wages fall in response to job destruction their proximity to benefits may reduce supply while if the minimum wage is increased to avoid incentive problems - as in Hungary - demand may fall further.

In sum, we have found evidence of common changes that herald a bleak future for the employment prospects of those with low skills or education. While incentive problems may be a serious part of the unemployment problem in this segment of the labour market, our paper suggests that demand-side developments may be equally important. Yet, sadly, crosscountry evidence on the evolution of educational spending since the start of transition shows that most countries have experienced substantial declines in education spending with associated falls in the quality of educational services. Such falls have been sharpest in the CIS and, in particular, in the poorer countries of that region ${ }^{27}$. The conclusions of this paper suggest that aside from raising the share of resources devoted to education, there is a need to change the content of education. In particular, the reform of vocational training and certification and the relationship with other educational streams remains a priority. Without such initiatives, the longer run implications for employment and inequality may be highly adverse.

\section{References}

Aghion, Philippe and S. Commander (1999), 'On the dynamics of inequality in the transition', Economics of Transition, 7, 2, 275-298

Autor, David, L. Katz and A.B. Krueger (1998), 'Computing Inequality: Have Computers changed the Labour Market?', Quarterly Journal of Economics, 113, 4, 1169-1214

Bilsen, V. and J. Konings (1998): Job creation, job destruction and growth of newly established, privatised, and state-owned enterprises in transition economies: Survey evidence from Bulgaria, Hungary, and Romania, Journal of Comparative Economics, September.

Boeri, Tito (2001): Transition with labour supply, WDI

Bresnahan, Timothy, E. Brynjolfsson and L. Hitt (2001), 'Information Technology, Workplace Organisation and the Demand for Skilled Labour', Quarterly Journal of Economics, forthcoming

\footnotetext{
${ }^{27}$ See UNICEF (2001)
} 
Brown, David and J. Earle (2001): Gross job flows in Russian industry before and after the reforms: Has destruction become more creative?, IZA DP No 351

Chennells, Lucy and J. Van Reenen, (1999), 'Has Technology Hurt Less Skilled Workers?' Institute for Fiscal Studies Working Paper, 99-27, London

Commander, Simon, J. McHale and R. Yemtsov (1995), 'Russia', in Simon Commander and Fabrizio Coricelli (editors), 'Unemployment, Restructuring and the Labour Market in Eastern Europe and Russia', Washington DC

Commander, Simon, A. Tolstopiatenko and R. Yemtsov (1999), 'Channels of Redistribution: Inequality and Poverty in the Russian Transition', Economics of Transition, 7, 2, 411-447

Davis, Steven J., and J. Haltiwanger (1992): Gross job creation, gross job destruction, and employment reallocation, Quarterly Journal of Economics, 107, 3, 819-63

European Bank for Reconstruction and Development, (2000 and 2001), 'Transition Report', London

European Commission (2000): Employment in Europe 2001. Recent trends and prospects, Luxembourg, 2001

Falk, Martin (2001), 'Diffusion of Information Technology, Internet Use and the Demand for Heterogeneous Labour', ZEW Discussion Paper No.01-48, Mannheim

Flanagan, Robert (1995), 'Labour market responses to a change in economic system', Proceedings of the World bank Annual Bank Conference on Development Economics, 1994, Washington DC

Jurajda and Terrell t.b.a.

Kertesi, G and J. Kollo (2001a), 'Economic transformation and the return to human capital: the case of Hungary, 1986-1998', Paper presented at the conference „Understanding Skill Obsolescence -Theoretical Innovations and Empirical Applications", May 10-12, Maastricht.

Kertesi, G and J. Kollo (2001b), Demand for Unskilled, Young-Skilled, and Older Skilled Workers - Evidence on Large Hungarian Firms', Institute of Economics, Budapest

Konings, J, H. Lehmann and M. Schaffer, 1996, 'Job Creation and Job Destruction in a Transition Economy: Ownership, Firm Size and Gross Flows in Polish Manufacturing, 1988-1991, Labour Economics, 3, 3, 299-317

Lehmann, H and J. Wadsworth, (2000), 'Tenures that shook the world: Worker Turnover in Russia, Poland and Britain', Journal of Comparative Economics, 28, 639-664 
Munich, Daniel, J. Svejnar and K. Terrell, (1999), 'Returns to human capital under the communist wage grid', Journal of Comparative Economics, 27, 33-60

Newell, Andrew, (2001), 'The Distribution of Wages in Transition Countries', IZA Discussion Paper 267, Bonn, March

Statistics Canada (2000): Literacy in the information age, OECD and Ministry of Industry, Canada

OECD (1998): Technology, Productivity and Job creation, Paris

UNICEF, (2001) 'Transmonee Database', Florence

World Bank, (1996), 'World Development Report: From Plan to Market', Washington DC 
Table 1: Sample characteristics

\begin{tabular}{lrrr}
\hline & Hungary & Romania & Russia \\
\hline Number of firms & 302 & 319 & 300 \\
Employees (2000) & 68,219 & 332,738 & 205,633 \\
Median size of firms & 100 & 204 & 155 \\
Number of manufacturing firms & 203 & 184 & 156 \\
Other sectors ('tertiary') & 99 & 135 & 144 \\
& & & \\
Small firms (<50 employees) & 87 & 110 & 74 \\
Medium-sized firms (50-249 employees) & 128 & 88 & 115 \\
Large firms (>=250 employees) & 87 & 121 & 111 \\
& & & \\
Established in or after 1990 & 78 & 123 & 56 \\
Majority foreign-owned ( $>50$ per cent) & 55 & 54 & 8 \\
Average age of equipment $<10$ years & 106 & 157 & 143 \\
Share of 'new' firms in manufacturing & 31.0 & 66.3 & 28.9 \\
Share of 'new' firms in tertiary sector & 44.4 & 61.8 & 75.7 \\
& & & \\
\hline
\end{tabular}

a) Old $=$ domestic and established before 1990 and equipment older than 10 years

b) New $=$ majority foreign or established after 1989 or equipment younger than 10 years

Table 2: Job reallocation rates (all firms)

\begin{tabular}{|c|c|c|c|c|c|}
\hline & Creation & Destruction & Reallocation & Net change & Excess reall. \\
\hline \multicolumn{6}{|l|}{ Hungary } \\
\hline 1997-1998 & 5.2 & -5.4 & 10.6 & -0.2 & 10.4 \\
\hline 1998-1999 & 4.6 & -5.9 & 11.5 & -1.3 & 10.2 \\
\hline 1999-2000 & 5.6 & -4.0 & 9.6 & 1.6 & 8.0 \\
\hline \multicolumn{6}{|c|}{ Bilsen-Konings (1997) } \\
\hline $1993-1994$ & 1.2 & -8.5 & 9.7 & -7.3 & 2.4 \\
\hline \multicolumn{6}{|l|}{ Romania } \\
\hline 1998-1999 & 3.6 & -11.6 & 15.2 & -8.0 & 7.2 \\
\hline 1999-2000 & 2.6 & -9.2 & 11.8 & -6.6 & 5.2 \\
\hline \multicolumn{6}{|c|}{ Bilsen-Konings (1997) } \\
\hline 1993-1994 & 0.9 & -5.7 & 6.8 & -4.8 & 2.0 \\
\hline \multicolumn{6}{|l|}{ Russia } \\
\hline 1998-1999 & 5.4 & -7.8 & 13.2 & -2.4 & 10.8 \\
\hline 1999-2000 & 3.6 & -2.4 & 6.0 & 1.2 & 4.8 \\
\hline \multicolumn{6}{|c|}{ Brown-Earle (2001) } \\
\hline $1998-1999$ & 4.1 & -7.3 & 11.4 & -3.2 & 8.2 \\
\hline 1991-99 average & 2.4 & -10.3 & 12.7 & -8.0 & 4.7 \\
\hline
\end{tabular}


Table 3: The net relative change of employment

(Net change as a percentage of the mid-period stock: 1997/2000 for Hungary and Russia; $1998 / 2000$ for Romania)

\begin{tabular}{|c|c|c|c|c|c|}
\hline Education: & primary & vocational & secondary & higher & total \\
\hline \multicolumn{6}{|l|}{ Hungary } \\
\hline unskilled blue collar & -7.6 & 19.2 & 14.4 & & -1.7 \\
\hline skilled blue collar & -9.7 & -4.0 & 9.3 & & -1.7 \\
\hline white collar & -41.3 & 7.7 & 4.3 & 8.7 & 4.8 \\
\hline Manager & & -9.8 & 1.6 & 4.9 & 2.0 \\
\hline Total & -8.2 & -1.0 & 6.3 & 6.6 & -0.4 \\
\hline \multicolumn{6}{|l|}{$\underline{\text { Romania }}$} \\
\hline unskilled blue collar & -38.8 & -24.2 & 14.9 & & -32.3 \\
\hline skilled blue collar & -4.6 & -19.9 & 6.4 & -8.9 & -13.8 \\
\hline white collar & -52.7 & -6.2 & -9.7 & -3.5 & -7.2 \\
\hline Manager & & & -6.3 & 1.2 & 0.1 \\
\hline Total & -16.1 & -19.6 & -8.9 & -2.5 & -12.8 \\
\hline \multicolumn{6}{|l|}{$\underline{\text { Russia }}$} \\
\hline unskilled blue collar & -14.1 & -19.8 & -10.8 & 1.4 & -11.7 \\
\hline skilled blue collar & -12.0 & 8.5 & 3.0 & 9.7 & 2.8 \\
\hline white collar & 3.6 & -0.5 & 11.0 & 9.4 & 6.1 \\
\hline Manager & -34.1 & -4.5 & -11.6 & 6.0 & 1.5 \\
\hline Total & -12.7 & 2.9 & 1.9 & 7.6 & 1.0 \\
\hline
\end{tabular}


Table 4: The contribution of sectors to change of employment within the most important skill groups (Net change in the sector/base-period stock of jobs in all sectors, by skill)

\begin{tabular}{|c|c|c|c|c|c|}
\hline \multirow{2}{*}{\multicolumn{2}{|c|}{ Hungary 1997-2000 }} & \multicolumn{2}{|c|}{ Manufacturing } & \multicolumn{2}{|c|}{ Tertiary } \\
\hline & & old & new & old & new \\
\hline \multirow[t]{3}{*}{ Unskilled b.c. } & primary & -5.1 & -3.0 & 0.5 & -0.0 \\
\hline & vocational & 2.6 & 12.5 & 4.2 & -0.0 \\
\hline & secondary & 0.6 & 12.5 & 1.2 & 0.1 \\
\hline \multirow{3}{*}{$\begin{array}{l}\text { Skilled blue } \\
\text { col. }\end{array}$} & primary & -9.8 & -2.0 & 0.9 & 1.2 \\
\hline & vocational & -5.0 & 1.2 & -0.2 & 0.0 \\
\hline & secondary & -1.8 & 6.5 & 1.1 & 3.5 \\
\hline \multirow[t]{3}{*}{ White collar . } & vocational & -4.7 & -0.7 & 11.2 & 1.8 \\
\hline & secondary & -1.9 & 2.0 & 1.9 & 2.4 \\
\hline & higher & 0.1 & 3.6 & 2.8 & 2.2 \\
\hline \multirow[t]{2}{*}{ Manager. } & secondary & -5.7 & 5.0 & 4.2 & -1.8 \\
\hline & higher & -3.9 & 4.5 & 1.2 & 3.1 \\
\hline \multicolumn{2}{|c|}{ Romania 1998-2000 } & $\begin{array}{l}\text { Manufa } \\
\text { old }\end{array}$ & new & $\begin{array}{l}\text { Tert } \\
\text { old }\end{array}$ & new \\
\hline \multirow{3}{*}{$\begin{array}{l}\text { Unskilled b. } \\
\text { c. }\end{array}$} & $\overline{\text { primary }}$ & -28.0 & -3.2 & 0.9 & -2.0 \\
\hline & vocational & -7.2 & -0.3 & -13.3 & 1.0 \\
\hline & secondary & -1.7 & 3.6 & 3.1 & 11.1 \\
\hline \multirow{3}{*}{$\begin{array}{l}\text { Skilled blue } \\
\text { col. }\end{array}$} & primary & -9.7 & -1.8 & 10.8 & 0.5 \\
\hline & vocational & -12.5 & -1.2 & -3.4 & -0.8 \\
\hline & secondary & -5.2 & -0.4 & -5.4 & 1.8 \\
\hline \multirow[t]{3}{*}{ White collar } & vocational & -14.0 & -7.7 & -1.4 & 3.3 \\
\hline & secondary & -7.9 & -0.0 & -1.1 & -0.9 \\
\hline & higher & -7.3 & 0.0 & -0.9 & 3.9 \\
\hline \multirow[t]{2}{*}{ Manager. } & secondary & -6.3 & 1.0 & 3.4 & -8.5 \\
\hline & higher & -1.7 & -0.4 & 0.4 & 2.5 \\
\hline
\end{tabular}


Table 5: Variations in the net rates

\begin{tabular}{|c|c|c|c|c|}
\hline \multirow{2}{*}{$\begin{array}{l}\text { Dependent variable: } \\
\text { net rates in firm-skill- } \\
\text { education cells }\end{array}$} & \multicolumn{2}{|c|}{$\begin{array}{l}\text { Hungary } \\
1997-2000\end{array}$} & \multicolumn{2}{|c|}{$\begin{array}{l}\text { Romania } \\
1998-2000\end{array}$} \\
\hline & Coefficient & $\mathrm{t}$ & Coefficient & $\mathrm{t}$ \\
\hline $\begin{array}{l}\text { Unskilled blue collar } \\
\text { primary }\end{array}$ & 0 & & 0 & \\
\hline vocational & .3202 & 3.08 & .2405 & 2.19 \\
\hline secondary & .2894 & 2.12 & .3068 & 2.38 \\
\hline higher & .7605 & 1.99 & 1.354 & 2.43 \\
\hline $\begin{array}{l}\text { Skilled blue collar } \\
\text { primary }\end{array}$ & .0084 & 0.04 & .0701 & 0.82 \\
\hline vocational & .0684 & 1.05 & .0592 & 0.92 \\
\hline secondary & .2674 & 3.45 & .1539 & 2.27 \\
\hline higher & .6312 & 3.22 & .6227 & 3.61 \\
\hline $\begin{array}{l}\text { White collar } \\
\text { primary }\end{array}$ & -.3140 & -2.22 & .1312 & 0.96 \\
\hline vocational & -.0584 & -0.54 & .0419 & 0.35 \\
\hline secondary & .0876 & 1.35 & .1365 & 2.21 \\
\hline higher & .2903 & 2.78 & .2265 & 3.17 \\
\hline Manager & & & & \\
\hline primary & -.3224 & -1.40 & & \\
\hline vocational & .1359 & 1.09 & .6235 & 2.42 \\
\hline secondary & .0981 & 1.47 & .2624 & 2.99 \\
\hline higher & .1424 & 2.20 & .2237 & 3.70 \\
\hline Manufact - new & .2243 & 5.52 & .2800 & 6.58 \\
\hline Tertiary - old & .0705 & 1.41 & .1028 & 2.44 \\
\hline Tertiary - new & .1077 & 1.70 & .3874 & 8.19 \\
\hline Size $<50$ & .0762 & 1.54 & -.0888 & -1.85 \\
\hline Size $>250$ & .1177 & 3.03 & .0354 & 0.92 \\
\hline Constant & -.2099 & -3.75 & -.3969 & -6.41 \\
\hline $\mathrm{N}$ of obs. & 2107 & & 2216 & \\
\hline $\mathrm{F}$ & 5.82 & & 7.16 & \\
\hline Prob. & 0.0000 & & 0.0000 & \\
\hline aR2 & 0.0520 & & 0.0591 & \\
\hline
\end{tabular}

Cases are unweighted *) Standard errors adjusted for clustering by firms. 
Table 6: Net rates by education

\begin{tabular}{|c|c|c|c|c|c|c|c|c|c|}
\hline & \multicolumn{3}{|c|}{ Hungary } & \multicolumn{3}{|c|}{ Romania } & \multicolumn{3}{|c|}{ Russia } \\
\hline & overall & $\begin{array}{c}\text { firm- } \\
\text { specific }\end{array}$ & $\begin{array}{l}\text { intra- } \\
\text { firm }\end{array}$ & Overall & $\begin{array}{c}\text { firm- } \\
\text { specific }\end{array}$ & $\begin{array}{l}\text { Intra- } \\
\text { firm }\end{array}$ & overall & $\begin{array}{c}\text { firm- } \\
\text { specific }\end{array}$ & $\begin{array}{l}\text { intra- } \\
\text { firm }\end{array}$ \\
\hline Primary & -8.2 & -3.6 & -4.6 & -35.3 & -22.9 & -12.4 & -12.7 & -7.7 & -5.0 \\
\hline Vocationl & -1.0 & -5.8 & 4.8 & -19.5 & -28.3 & 8.8 & 2.9 & -3.9 & 6.8 \\
\hline Secondy & 6.3 & 2.7 & 9.0 & 2.1 & -15.1 & 17.2 & 1.9 & -6.0 & 7.9 \\
\hline Higher & 6.6 & 7.1 & -0.5 & 8.0 & -15.7 & 23.7 & 7.6 & -4.9 & 12.5 \\
\hline
\end{tabular}

Table 7: Inner Products of Changes in Relative Wages

\begin{tabular}{rrrr}
\hline \multicolumn{5}{c}{ Hungary } \\
\hline $1998-1997$ & $1999-1998$ & $2000-1999$ & $2000-1997$ \\
0.145 & 0.037 & 0.041 & 0.168 \\
\hline \multicolumn{5}{c}{ Romania } \\
\hline $1998-1997$ & $1999-1998$ & $2000-1999$ & $2000-1997$ \\
0.083 & -0.027 & -0.062 & 0.137 \\
\hline
\end{tabular}

Table 8: Changes in Demand for Labour: Between and within effects

\begin{tabular}{|c|c|c|c|c|c|c|c|c|c|c|c|c|}
\hline \multicolumn{13}{|c|}{ Hungary } \\
\hline & Bet & Bet & Bet & Wit & Wit & Wit & Ove & Ove & Ove & Bet & Wit & Ove \\
\hline & w- & w- & w- & h-in & h-in & h-in & r-all & r-all & r-all & w- & h-in & r-all \\
\hline & een & een & een & & & & & & & een & & \\
\hline & 199 & 199 & 200 & 199 & 199 & 200 & 199 & 199 & 200 & 200 & 200 & 200 \\
\hline & $8 / 97$ & 9/98 & 0/99 & $8 / 97$ & 9/98 & 0/99 & $8 / 97$ & 9/98 & 0/99 & 0/97 & $0 / 97$ & 0/97 \\
\hline High & 1.4 & 0.4 & 1.9 & -0.1 & 2.3 & 0.3 & 1.3 & 2.6 & 2.2 & 3.6 & 2.4 & 6.0 \\
\hline Voc & 1.1 & -0.2 & 1.6 & -0.2 & 1.7 & -0.7 & 0.9 & 1.5 & 0.9 & 2.5 & 0.8 & 3.3 \\
\hline $\mathrm{Sec}$ & 1.2 & -0.7 & 1.5 & -0.4 & -1.3 & -0.6 & 0.8 & -2.0 & 0.9 & 2.1 & -2.4 & -0.3 \\
\hline Pri & 0.7 & -1.8 & 1.9 & -2.0 & 0.5 & -0.6 & -1.3 & -1.4 & 1.3 & 0.7 & -2.1 & -1.4 \\
\hline
\end{tabular}

\begin{tabular}{|c|c|c|c|c|c|c|c|c|c|c|c|c|}
\hline \multicolumn{13}{|c|}{ Romania } \\
\hline & Bet & Bet & Bet & Wit & Wit & Wit & Ove & Ove & Ove & Bet & Wit & Ove \\
\hline & $\begin{array}{l}\text { W- } \\
\text { een }\end{array}$ & $\begin{array}{l}\text { W- } \\
\text { een }\end{array}$ & $\begin{array}{l}\text { W- } \\
\text { een }\end{array}$ & h-in & h-in & h-in & r-all & r-all & r-all & $\begin{array}{l}\text { w- } \\
\text { een }\end{array}$ & h-in & r-all \\
\hline & 199 & 199 & 200 & 199 & 199 & 200 & 199 & 199 & 200 & 200 & 200 & 200 \\
\hline & $8 / 97$ & 9/98 & $0 / 99$ & $8 / 97$ & 9/98 & $0 / 99$ & $8 / 97$ & 9/98 & 0/99 & 0/97 & $0 / 97$ & $0 / 97$ \\
\hline High & 7.7 & -4.4 & -2.9 & 5.1 & 3.2 & 0.3 & 12.3 & -1.0 & -2.6 & 0.8 & 8.4 & 9.2 \\
\hline Voc & 7.5 & -5.1 & -3.6 & 3.1 & -1.4 & -0.4 & 10.3 & -6.5 & -4.1 & -0.8 & 1.4 & 0.6 \\
\hline $\mathrm{Sec}$ & 1.9 & -6.6 & -6.2 & 3.4 & -3.1 & -1.9 & 5.3 & - & -8.2 & - & -1.5 & - \\
\hline & & & & & & & & 10.0 & & 11.0 & & 12.7 \\
\hline Pri & 3.8 & -6.2 & -5.5 & -3.1 & 2.2 & 3.9 & 0.8 & -3.8 & -1.5 & -7.8 & 3.1 & -4.5 \\
\hline
\end{tabular}


Table 9: Log changes of relative wages, 1997-2000, Russia

\begin{tabular}{lcccc}
\hline $\begin{array}{l}\text { Firms where employment } \\
\text { of the given skill category: }\end{array}$ & Blue collar & $\begin{array}{c}\text { Skilled blue } \\
\text { c.. }\end{array}$ & White collar & Manager \\
\hline - decreased & -.1681 & .0022 & .0408 & -.0381 \\
- did not change & -.1390 & .0242 & -.0767 & .0246 \\
- increased & .1017 & .0200 & -.0158 & -.0326 \\
Overall change & -.1245 & .0093 & .0135 & -.0315 \\
Number of reporting firms & 203 & 231 & 265 & 264 \\
$\begin{array}{l}\text { F-test for difference } \\
\text { between }\end{array}$ & 28.2 & 0.27 & 0.89 & 0.02 \\
$\begin{array}{l}\text { increasing and decreasing } \\
\text { firms }\end{array}$ & .0000 & n.s. & n.s. & n.s. \\
Mean changes weighted with the mid-period number of workers & & \\
\hline
\end{tabular}

Table 10: Estimates of $R_{j}$ and $S_{j}$ (per cent of destruction and creation, respectively)

\begin{tabular}{lcccccc}
\hline & \multicolumn{2}{c}{ Unskilled blue collars } & \multicolumn{2}{c}{ Skilled blue collars } & \multicolumn{2}{c}{ White collars } \\
\hline & $\mathrm{R}_{\mathrm{j}}$ & $\mathrm{S}_{\mathrm{j}}$ & $\mathrm{R}_{\mathrm{j}}$ & $\mathrm{S}_{\mathrm{j}}$ & $\mathrm{R}_{\mathrm{j}}$ & $\mathrm{S}_{\mathrm{j}}$ \\
Hungary & 14.8 & 35.3 & 9.9 & 30.9 & 11.6 & 21.7 \\
Romania & 1.9 & 15.1 & 8.9 & 18.4 & 16.0 & 34.5 \\
Russia & n.a. & n.a. & 49.0 & 22.1 & 11.7 & 19.6 \\
\hline
\end{tabular}


Table 11: Firms reporting redundant workers or 'shortages'

\begin{tabular}{|c|c|c|c|c|c|c|}
\hline \multirow{3}{*}{$\begin{array}{l}\text { Level of } \\
\text { employment: }\end{array}$} & \multicolumn{3}{|c|}{ Actual $>$ desirable } & \multicolumn{3}{|c|}{ Actual $<$ desirable } \\
\hline & \multirow{2}{*}{$\begin{array}{l}\text { Pct of } \\
\text { firms }\end{array}$} & \multicolumn{2}{|c|}{$\begin{array}{c}\text { Pct of } \\
\text { workers }^{\mathrm{a}}\end{array}$} & \multirow{2}{*}{$\begin{array}{l}\text { Pct of } \\
\text { firms }\end{array}$} & \multicolumn{2}{|c|}{$\begin{array}{c}\text { Pct of } \\
\text { workers }\end{array}$} \\
\hline & & lower & upper & & lower & upper \\
\hline \multicolumn{7}{|l|}{ Hungary } \\
\hline Blue collar & 7.3 & 1.2 & 1.5 & 11.2 & 1.5 & 2.4 \\
\hline Skilled blue collar & 3.0 & 0.7 & 1.0 & 35.8 & 3.2 & 4.5 \\
\hline White collar & 9.0 & 3.6 & 3.7 & 9.9 & 0.4 & 0.4 \\
\hline Manager & 5.3 & 1.0 & 1.1 & 7.0 & 0.7 & 0.7 \\
\hline \multicolumn{7}{|l|}{ Romania } \\
\hline Blue collar & 10.9 & 1.9 & 2.1 & 6.3 & 0.4 & 0.5 \\
\hline Skilled blue collar & 7.8 & 1.4 & 1.4 & 16.6 & 3.5 & 5.4 \\
\hline White collar & 12.9 & 1.5 & 1.5 & 11.9 & 2.1 & 2.2 \\
\hline Manager & 6.6 & 0.3 & 0.3 & 4.4 & 0.8 & 0.9 \\
\hline \multicolumn{7}{|l|}{ Russia } \\
\hline Blue collar & 6.0 & 2.5 & 3.3 & 12.0 & 1.0 & 1.5 \\
\hline Skilled blue collar & 4.7 & 0.5 & 0.8 & 36.7 & 2.5 & 4.1 \\
\hline White collar & 10.3 & 1.4 & 1.5 & 21.6 & 1.3 & 1.6 \\
\hline Manager & 10.3 & 2.1 & 2.3 & 7.0 & 0.4 & 0.4 \\
\hline \multicolumn{7}{|c|}{$\begin{array}{l}\text { a) Lower (upper) limit was estimated assuming redundant labour is } 25(40) \\
\text { per cent of the actual staff in firms reporting redundancies above } 20 \text { per cent. } \\
\text { b) Logit coefficients - see the text. } \\
\text { c) Significant at } .001 \mathrm{~d} \text { ) } 0.05 \text { e) } 0.1 \text { level. } \\
\text { f) Lower (upper) limit: assuming missing labour is } 15(25) \text { per cent of the } \\
\text { actual staff in firms reporting redundancies above } 10 \text { per cent. }\end{array}$} \\
\hline
\end{tabular}


Table 12: Own-wage and cross-wage elasticities evaluated at the sample means

\begin{tabular}{|c|c|c|c|c|c|c|c|c|c|}
\hline \multicolumn{10}{|c|}{ (i) All sectors } \\
\hline & \multicolumn{3}{|c|}{ Hungary } & \multicolumn{3}{|c|}{ Romania } & \multicolumn{3}{|c|}{ Russia } \\
\hline & $\mathrm{Bcu}$ & bcs & wc & bcu & bcs & wc & bcu & bcs & $\mathrm{wc}$ \\
\hline $\mathrm{bcu}^{\mathrm{a}}$ & -0.486 & 0.431 & .0555 & -0.426 & 0.025 & 0.402 & -0.462 & 0.466 & -0.004 \\
\hline bcs ${ }^{b}$ & 0.263 & -0.439 & 0.176 & 0.003 & -0.089 & 0.086 & 0.076 & -0.067 & -0.009 \\
\hline $\mathrm{wc}^{\mathrm{c}}$ & 0.041 & 0.218 & -0.259 & 0.082 & 0.124 & -0.206 & -0.001 & -0.011 & 0.012 \\
\hline \multicolumn{10}{|c|}{ (ii) Manufacturing } \\
\hline & \multicolumn{3}{|c|}{ Hungary } & \multicolumn{3}{|c|}{ Romania } & \multicolumn{3}{|c|}{ Russia } \\
\hline & bcu & bcs & wc & bcu & bcs & wc & bcu & bcs & Wc \\
\hline $\mathrm{bcu}^{\mathrm{a}}$ & -0.392 & 0.459 & -0.062 & -0.535 & -0.013 & 0.547 & -0.349 & 0.775 & -0.427 \\
\hline bcs ${ }^{b}$ & 0.367 & -0.501 & 0.133 & -0.002 & -0.156 & 0.156 & 0.119 & -0.153 & 0.034 \\
\hline $\mathrm{wc}^{\mathrm{c}}$ & -0.067 & 0.181 & -0.114 & 0.133 & 0.259 & -0.392 & -0.106 & 0.055 & 0.051 \\
\hline
\end{tabular}

a) Unskilled blue collars b) Skilled blue collars c) White collars including managers 
